\title{
Potential Applications of Molecular Markers in Plant
}

\author{
Lincoln Mandal ${ }^{1 *}$, Sunil Kumar Verma ${ }^{2}$, Saugato Sasmal ${ }^{3}$ and Jawaharlal Katara ${ }^{4}$ \\ ${ }^{1}$ Department of Agriculture and Biotechnology, India \\ ${ }^{2}$ Department of Genetics and Plant Breeding, India \\ ${ }^{3}$ Krishi Vigyan Kendra, India \\ ${ }^{4}$ Department of Plant Biotechnology, National Rice Research Institute, India
}

Submission: February 02, 2018; Published: March 14, 2018

*Corresponding author: Lincoln Mandal, Department of Agriculture and Biotechnology, CG, Raipur - 492012, India, Email: Indialincolndbt@gmail.com

\begin{abstract}
Marker may be defined as "Mark of identification". Molecular markers have several advantages over the traditional phenotypic and biochemical markers in plant. The main uses of DNA markers in agricultural research such as Cultivar identity/assessment of 'purity' / Hybrid Testing, Genetic Diversity Analysis, Genetic Linkage Map Construction, Mapping of quantitative trait loci (QTLs), Map based cloning of genes, Mapping of mutations, Marker-assisted selection (MAS), Marker assisted backcross breeding (MAB), Marker-assisted pyramiding, Mapping major genes, Characterization of transformants etc. DNA markers are widely accepted as potentially valuable tools for crop improvement in plant.

Keywords : Molecular marker; Mapping; MAS; Pyramiding; QTLs
\end{abstract}

\section{Introduction}

Molecular marker may be defined as any site (locus) in the genome of an organism at which the DNA base sequence varies among the different individuals of a population. Such markers generally have no apparent effect on the phenotype of the individual. Genetic markers represent genetic differences between individual organisms or species. Generally, they do not represent the target genes themselves but act as 'signs'or 'flags'. Genetic markers that are located in close proximity to genes (i.e. tightly linked) may be referred to as gene 'tags'. DNA (or molecular) markers a type of genetic markers, which reveal sites of variation in DNA [1,2].

\section{Potential Applications in Plant}

\section{Cultivar identity/assessment of 'purity' / Hybrid Testing}

Markers can be used to confirm the true identity of individual plants. The maintenance of high levels of genetic purity is essential in cereal hybrid production in order to exploit heterosis. In hybrid rice, SSR and STS markers were used to confirm purity, which was considerably simpler than the standard 'grow-out tests' that involve growing the plant to maturity and assessing morphological and floral characteristics [3].

\section{Genetic Diversity Analysis/ Population genetics}

DNA markers are useful in the assessment of genetic diversity in germplasm, cultivars and advanced breeding material using several techniques, such as restriction fragment length polymorphism (RFLP), random amplified polymorphic DNA (RAPD), amplified fragment length polymorphism (AFLP) and microsatellites. In general, type II markers such as RAPDs, microsatellites, and AFLPs are considered to be non-coding. Such markers have found widespread use in population genetic studies [4]. SSR marker based genetic diversity analysis of modern rice varities and coastal landraces [5]. RAPD-PCR (randomly amplified polymorphic DNA polymerase chain reaction) for a study of the genetic diversity within and among 20 populations of Geum reptans, an outcrossing clonal plant species in the Swiss Alps [6].

\section{Genetic Linkage Map Construction}

Genetic linkage maps an important tool in genetic and genomic research. DNA markers can be used for constructing genetic linkage maps [7]. A 2275-marker genetic map of rice (Oryza sativa L.) covering $1521.6 \mathrm{cM}$ in the Kosambi function has been constructed [8]. A universal core genetic map developed for rice [9].

\section{Mapping of quantitative trait loci (QTLs)}

Quantitative trait locus (QTL) analysis is a statistical method that links two types of information-phenotypic data (trait measurements) and genotypic data (usually molecular markers)in an attempt to explain the genetic basis of variation in complex traits [10-12]. The first high-density genetic linkage map for $P$. haitanensis was constructed and fifteen QTLs associated with six economically important traits were identified [13]. Genetic Linkage Map Construction and QTL analysis of Two Inter specific Reproductive Isolation Traits in Sponge Gourd [14]. 


\section{Mapping of simple traits/ Mapping major genes}

Molecular markers are used in molecular biology and biotechnology to identify a particular sequence of DNA in a pool of unknown DNA. Genes conferring resistance to the bacterial blight e.g. xa5 [15], Xa2 [16], Xa25(b) [17] and Rice Blast resistance genes e.g. Pi24 [18].

\section{Mapping of mutations}

Genetic mapping of a mutation-defined gene is the first step toward isolating and cloning the corresponding normal gene and ultimately identifying its encoded protein. Genetic mapping using next-generation sequencing that combines single nucleotide polymorphism discovery, mutation localization and potential identification of causal sequence variants [19]. CandiSNP is a user-friendly application that will aid in novel discoveries from forward-genetic mutant screens [20].

\section{Map based cloning of genes}

Map-based cloning or positional cloning is the process to recognize the genetic basis of a mutant phenotype with the help of linkage to markers whose physical location in the genome is known. Map-Based Cloning of the gene associated with the soybean maturity locus E3 [21]. Map-based cloning of BPH26 revealed that $B P H 26$ encodes a coiled-coil-nucleotide-bindingsite-leucine-rich repeat (CC-NBS-LRR) protein [22]. Isolation of Pto gene in tomato [23] and $X a-1$ gene in rice [24]. Positional cloning of several QTL including Brix9-2-5, fw 2.2, Hd1, Hd6, FRI in tomato, Rice and Arabidopsis. MOC-1 is 1st gene isolated for Rice tillering using Map based cloning approach [25].

\section{Marker-assisted selection (MAS)}

Once tightly linked markers have been identified to the genes or QTLs, they should be used for MAS. DNA markers are used in the marker assisted or marker aided selection. MAS have several advantages over straight selection. Ribaut \& Betran [26] proposed involving MAS at an early generation was called single large-scale MAS (SLS-MAS). MAS for simply inherited traits are gaining increasing importance in breeding programs, allowing an acceleration of the breeding process [27].

\section{Marker-assisted pyramiding}

Pyramiding is the simultaneous integration of multiple genes/QTLs into a single genotype. DNA markers may facilitate selection, without phenotyping. The most widely application of pyramiding is the integration of multiple disease resistance genes into a plant to develop "durable" or stable resistance to a disease. For example, Hittalmani et al. [28] combined genes originating from three parents for rice blast resistance using RFLP, STS markers. The combination of quantitative resistance was the pyramiding of a single stripe rust gene and two QTLs using SSR marker [29].

\section{Marker assisted back cross breeding (MAB)}

Backcrossing is a plant breeding method most commonly used to incorporate one or a few genes into an adapted or elite variety. The use of DNA markers in backcrossing greatly increases the efficiency of selection. The bacterial blight resistance genes $x a 5, x a 13$ and Xa21 foreground selection by STS marker [30], Sub1 QTL select by phenotyping and SSR [31].

\section{Molecular taxonomy and evolution}

DNA markers are useful in the study of crop evolution. The development of increasingly informative molecular markers has allowed for detailed investigations of the evolution of a number of crops e.g. identification of crop progenitors [32-36].

\section{Identification of individuals}

More recently molecular markers, such as SNPs and simple sequence repeats (SSRs) have been developed for the selection of fragrant rice [37].

\section{Conclusion}

Molecular markers are widely used in crop improvement due to its simplicity, reproducibility and precise location. It is not affected to environmental effect reduce breeding cycle. Recently many markers are available, out of this SSR, SNP are mostly used in breeding programme and other study. Application of DNA marker technologies molecular also other areas of plant biology like systematics, population genetics, evolutionary biology and conservation genetics, advances in genomics and identification of the wild progenitors of domestic species, the establishment of geographic patterns of genetic diversity.

\section{References}

1. Jones N, Ougham H, Thomas H (1997) Markers and mapping: We are all geneticists now. New Phytol 137: 165-177.

2. Winter P, Kahl G (1995) Molecular marker technologies for plant improvement. World Journal of Microbiology \& Biotechnology 11: 438-448.

3. Yashitola J, Thirumurgan T, Sundaram RM, Naseerullah MK, Ramesha MS, et al. (2002) Assessment of purity of rice hybrid using microsatellite and STS markers. Crop Science 42: 1369-1373.

4. Brown B, Epifanio J (2003) Nuclear DNA. In: Hallermann EM (Ed.), Population Genetics: Principles and Applications for Fisheries Scientists. American Fisheries Society, Bethesda, MD. p. 458.

5. Shakil SK, Sultana S, Hasan MM, Hossain MM, Ali MS, et al. (2015) SSR marker based genetic diversity analysis of modern rice varities and coastal landraces in Bangladesh. Indian journal of Biotechnology 14: 33-41.

6. Pluess AR, Stöcklin J (2004) Population genetic diversity of the clonal plant Geumreptans (Rosaceae) in the Swiss Alps. American Journal of Botany 91(12): 2013-2021.

7. Khanal R, Navabi A, Lukens L (2015) Linkage map construction and quantitative trait loci (QTL) mapping using intermated vs. selfed recombinant inbred maize line (Zea mays L.). Can J Plant Sci 95: 11331144.

8. Harushima Y, Yano M, Shomura A, Sato M, Shimano T, et al. (1998) A high-density rice genetic linkage map with 2275 markers using a single $\mathrm{F}_{2}$ population. Genetics 148(1): 479-494.

9. Orjuela J, Garavito A, Bouniol M, Arbelaez JD, Moreno L, et al. (2010) A universal core genetic map for rice. Theoretical and Applied Genetics $120(3): 563-572$. 
10. Falconer DS, Mackay TFC (1996) Introduction to Quantitative Genetics. ( $4^{\text {th }}$ edn), London.

11. Kearsey MJ (1998) The principles of QTL analysis (a minimal mathematics approach). Journal of Experimental Botany 49: 16191623.

12. Lynch M, Walsh B (1998) Genetics and Analysis of Quantitative Traits.

13. Xu Y, Huang L, Ji D, Chen C, Zheng H, Xie C (2015) Construction of a dense genetic linkage map and mapping quantitative trait loci for economic traits of a doubled haploid population of Pyropiahaitanensis (Bangiales, Rhodophyta). BMC plant biology 15(1): 228.

14. Wu H, He X, Gong H, Luo S, Li M, et al. (2016) Genetic linkage map construction and QTL analysis of two interspecific reproductive isolation traits in sponge gourd. Frontiers in plant science 7: 980.

15. Iyer AS, McCouch SR (2004) The rice bacterial blight resistance gene xa5 encodes a novel form of disease resistance. Mol Plant-Microbe Interact 17: 1348-1354.

16. He Q Li DB, Zhu YS, Tan MP, Zhang DP, et al. (2006) Fine mapping of $\mathrm{X} a$ 2, a bacterial blight resistance gene in rice. Mol Breed 17: 1-6.

17. Chen H, Wang S, Zhang Q (2002) New gene for bacterial blight resistance in rice located on chromosome 12 identified from Minghui 63, an elite restorer line. Phytopathology 92: 750-754.

18. Sallaud C, Lorieux M, Roumen E, Tharreau D, Berruyer R, et al. (2003) Identification of five new blast resistance genes in the highly blastresistant rice variety IR64 using a QTL mapping strategy. Theor Appl Genet 106: 794-803.

19. Leshchiner I, Alexa K, Kelsey P, Adzhubei I, Austin-Tse CA, et al. (2012) Mutation mapping and identification by whole-genome sequencing. Genome Research 22: 1541-1548.

20. Etherington GJ, Monaghan J, Zipfel C, MacLean D (2014) Mapping mutations in plant genomes with the user-friendly web application CandiSNP. Plant methods 10(1): 41.

21. Watanabe S, Hideshima R, Xia Z, Tsubokura Y, Sato S, et al. (2009) Mapbased cloning of the gene associated with the soybean maturity locus E3. Genetics 182(4): 1251-1262.

22. Tamura Y, Hattori M, Yoshioka H, Yoshioka M, Takahashi A, et al. (2014) Map-based Cloning and Characterization of a Brown Planthopper Resistance Gene BPH26 from Oryza sativa L. ssp. indica Cultivar ADR52. Scientific Reports 4: 5872.

23. Martin GB, Brommonschenkel SH, Chunwongse J, Frary A, Ganal MW, et al. (1993) Map based cloning of a protein kinase gene conferring disease resistance in tomato. Science 262: 1432-1436.

24. Yoshimura S, Umehara Y, Kurata N, Nagamura Y, Sasaki T, et al. (1996) Identification of a YAC clone carrying the $X a-1$ allele, a bacterial blight resistance gene in rice. Theor Appl Genet 93: 117-122.
25. Li X, Qian Q, Fu Z, Wang Y, Xion Get al. (2003) Control of tillering in rice. Letter to nature 422: 618-621.

26. Ribaut JM, Betran J (1999) Single large-scale marker assisted selection (SLS-MAS). Mol Breed 5: 531-541.

27. Francia E, Tacconi G, Crosatti C, Barabaschi D, Bulgarelli D, et al. (2005) Marker assisted selection in crop plants. Plant Cell Tissue and Organ Culture 82: 317-342.

28. Hittalmani S, Parco A, Mew TV, Zeigler RS, Huang N (2000) Fine mapping and DNA marker-assisted pyramiding of the three major genes for blast resistance in rice. Theor Appl Genet 100: 1121-1128.

29. Castro AJ, Capettini F, Corey AE, Filichkina T, Hayes PM, et al. (2003) Mapping and pyramiding of qualitative and quantitative resistance to stripe rust in barley. Theor Appl Genet 107(5): 922-930.

30. Singh S, Sidhu JS, Huang N, Vikal Y, Li Z, Brar DS, Dhaliwal HS, Khush GS (2001) Pyramiding three bacterial blight resistance genes (xa5, xa13 and Xa21) using marker-assisted selection into indica rice cultivar PR106. Theor Appl Genet 102: 1011-1015.

31. Mackill DJ, Collard BCY, Neeraja CN, Maghirang- Rodriquez R, Heuer $S$, et al. (2006) QTLs in rice breeding: examples for abiotic stresses. In Fifth Int. Rice Genetics Symp., Manila, Philippines. Los Baños, The Philippines: International Rice Research Institute.

32. Brubaker CL, Wendel JF (1994) Reevaluating the origin of domesticated cotton (Gossypium hirsutum; Malvaceae) using nuclear restriction fragment length polymorphisms (RFLPs). American Journal of Botany 81: $1309-1326$

33. Jacobs J ME, Van Eck HJ, Arens P, Verkerk - Bakker B, Lintel Hekkert B, et al. (1995) A genetic map of potato (Solanumtuberosum) integrating molecular markers, including transposons, and classical markers. Theoretical and Applied Genetics 91: 289-300.

34. Matsuoka Y, Vigouroux Y, Goodman MM, Sanchez JG, Buckler E, et al. (2002) A single domestication for maize shown by multilocus microsatellite genotyping. Proceedings of the National Academy of Sciences USA 99: 6080-6084.

35. Harter AV, Gardner KA, Falush D, Lentz DL, Bye RA, et al. (2004) Origin of extant domesticated sunflowers in eastern North America. Nature 430: 201-205.

36. Konishi S, Izawa T, EbanaL SYK, Fukuta Y, Sasaki T, et al. (2006) A SNP caused loss of seed shattering during rice domestication. Science 312: 1392-1396.

37. Cordeiro GM, Christopher MJ, Henry RJ, Reinke RF (2002) Identification of microsatellite markers for fragrance in rice by analysis of the rice genome sequence. Mol Breed 9(4): 245-250.

This work is licensed under Creative

Commons Attribution 4.0 License

DOI: 10.19080/CTBEB.2018.12.555844
Your next submission with Juniper Publishers will reach you the below assets

- Quality Editorial service

- Swift Peer Review

- Reprints availability

- E-prints Service

- Manuscript Podcast for convenient understanding

- Global attainment for your research

- Manuscript accessibility in different formats

( Pdf, E-pub, Full Text, Audio)

- Unceasing customer service

Track the below URL for one-step submission https://juniperpublishers.com/online-submission.php 